\title{
Relationship Between Soil Organic Matter and Some Physical Properties in Selected Soils of the Oil Palm Belt of Nigeria
}

\author{
Osayande Pullen Efosa ${ }^{1 *} \quad$ Uwabor Chukwuma Stanley ${ }^{2} \quad$ Enohuma Stanley $^{3}$ Orhue Ehi Robert ${ }^{3}$ \\ 1.Soils and Land Management Division, Nigerian Institute for Oil Palm Research (NIFOR) P.M.B. 1030, Benin \\ City, Nigeria \\ 2.Agribusiness/Research \& Development Department, UIDC Ltd, Warri, Delta state, Nigeria \\ 3.Department of Soil Science and Land Management, Faculty of Agriculture, University of Benin, PMB 1030, \\ Benin City Nigeria
}

\begin{abstract}
Organic matter is related to all plant nutrients and is a major contributor to tropical soils cation exchange capacity. Its relationship with soils physical properties is currently undermined. Its deliberate inclusion in soils can be used to reverse soil compaction due to high bulk density with improved soil structure and texture. Its relationship with some physical properties such as bulk density, total porosity, particle size distribution (texture) and moisture content was studied in selected soils of the oil palm belt of Nigeria to determine the influence of organic matter on these properties. Such information will assist in the proper management of the soils physical properties for improved organic matter content of soils under oil palm. Results indicated that there was a significant difference in the sand and silt contents due to the influence of the soils parent materials with higher values of sand $(870.70 \mathrm{~g} / \mathrm{kg})$ recorded in soils under coastal plain sand while higher values of silt $(52.70 \mathrm{~g} / \mathrm{kg})$ were recorded in soils under alluvium. Soils under basement complex rocks had the highest clay $(116.40 \mathrm{~g} / \mathrm{kg})$ contents and bulk density values $\left(1.85 \mathrm{gcm}^{-3}\right)$. Highest moisture $(75.66 \%)$ content was recorded in soils under alluvium while the highest total porosity values were recorded in soils under shale mixed with sandstone and clay. The study concludes that sand and silt contents had positively significant correlations with organic matter of the soils. It is recommended that organic materials and residues from the oil palm biomass be ploughed back constantly to these soils for improved soil structure, porosity, moisture content and bulk density of the soils.
\end{abstract}

Keywords: Organic matter, oil palm belt, particle size distribution, bulk density and porosity

DOI: $10.7176 / \mathrm{JNSR} / 12-7-01$

Publication date: April $30^{\text {th }} 2021$

\section{INTRODUCTION}

The oil palm belt is the Southern part of Nigeria where it occupies about 2.53 million hectares (1). The soils covering these hectares are developed on different parent materials some of which are coastal plain sands, basement complex/sedimentary rocks, alluvium and shale mixed with sandstones and clay and includes soils such as Ultisols, Inceptisols, Oxisols, Alfisols and Entisols (2). The soils generally have low organic matter content due to high temperature and rainfall distribution (3). And contain low activity clay (LAC) that contributes very little to the cation exchange capacities of the soils. Major contributor to the soils CEC is the organic matter content of the soils. Soil organic matter is the highest contributor to the cation exchange capacity of tropical soils (4). Organic matter imparts on many soil properties such as colour and nutrient holding capacity of soils. It also influences water relations through its influence on soil texture and porosity (5). It therefore follows that the physical properties of a soil are as important as its chemical properties. Soils physical properties to a large extent determine how chemical constituents are released for plants' utilization. It has been shown that organic matter influences all soil properties (6). It regulates soil bulk density and helps to improve the aggregate stability of soils (4). It also enhances water infiltration and nutrient movement through soil. It follows that proper management of the nutrient content of soils must take into cognizance the relationship between organic matter content and soil physical properties such as bulk density, texture and moisture content of the soils. In view of this, a study was undertaken to determine the relationship between soil organic matter and some soils physical properties. Its objectives were to determine the:

1. relationship between soil organic matter content and physical properties such as bulk density, total porosity and moisture content of soils of oil palm under different parent materials

2. influence of the soils parent materials on physical properties of the soils

\section{MATERIALS AMD METHODS}

Description of the various study locations:

The study was undertaken in three states of South Southern Nigeria known for oil palm cultivation. The locations included Agbarho in Delta state, the Nigerian Institute for Oil Palm Research main station in Benin City, Onishere and Ubiaja in Ondo and Edo states respectively. The soils of the study locations were developed on different parent materials and therefore have varied mineralogy. The states (Edo, Delta and Ondo) are part of 
the oil palm belt of Nigeria.

\section{Soil sampling:}

The soils were sampled by use of profile pits from bottom to the top. Three profile pits were sited in each of the locations (Agbarho, Onishere, NIFOR and Ubiaja). At Agbarho, profile I was sited at $13 \mathrm{~m}$ ASL on Latitude N $05^{0} 04^{\prime} 33.4^{\prime \prime}$ and Longitude E $005^{\circ} 52^{\prime} 51.5^{\prime \prime}$, profile II was sited at $20 \mathrm{~m}$ ASL (N $05^{0} 34^{\prime} 31.2^{\prime \prime}$ and E $\left.005^{\circ} 52^{\prime} 50.0^{\prime \prime}\right)$

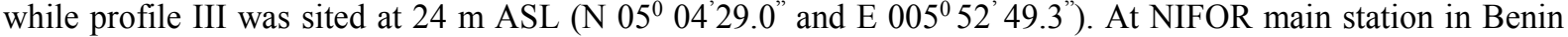
City, profile I was sited at 164 m ASL (N 06 ${ }^{0} 32^{\prime} 59.7^{\prime \prime}$, E005037'15.8”), profile II on $159 \mathrm{~m}$ ASL (N 06 $32^{\prime} 59.9^{\prime \prime}$, E $\left.005^{0} 37^{\prime} 18.5^{\prime \prime}\right)$, profile III on 160 ASL (N 06033'00.7”, E 005037'17.3”). At Onishere in Ondo state, profile I was sited on Latitude N $06^{\circ} 44^{\prime} 30.9^{\prime \prime}$ and Longitude E $005^{\circ} 05^{\prime} 10.6^{\prime \prime}$ with an elevation of 69 meters ASL. Profile II

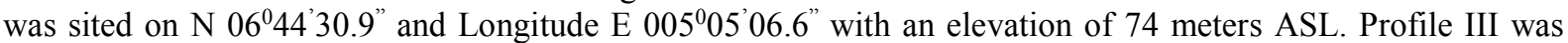
sited on N $06^{0} 44^{\prime} 25.4^{\prime \prime}$ and Longitude E 005 $04^{\circ} 59.5^{\prime \prime}$ At Ubiaja Profile I was located at an altitude of $342 \mathrm{~m} \mathrm{ASL}$

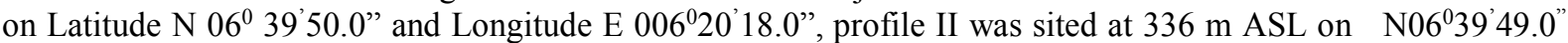
and Longitude E $006^{0} 20^{\prime} 14.4^{\prime \prime}$ while profile III was sited at 339 m ASL on Latitude N 06 39'53.9" and Longitude E $006^{0} 20^{\prime} 16.5$ ". Five soil depths namely $0-15 \mathrm{~cm}, 15-30 \mathrm{~cm}, 30-45 \mathrm{~cm}, 45-90 \mathrm{~cm}$ and $90-120 \mathrm{~cm}$ were marked out and sampled with the aid of a hand trowel from the bottom of the profiles to the top at Agbarho while six soil depths namely $0-15 \mathrm{~cm}, 15-30 \mathrm{~cm}, 30-45 \mathrm{~cm}, 45-60 \mathrm{~cm}, 60-90 \mathrm{~cm}$ and $90120 \mathrm{~cm}$ were sampled at the other locations. Core soil samples for the determination of moisture content, bulk density and porosity were taken at $0-15 \mathrm{~cm}$ and $90-120 \mathrm{~cm}$ soil depths. The soil samples were accurately labeled in polythene bags and transported to the laboratory for analysis.

\section{Laboratory analysis:}

The core samples were carefully placed in the oven after weighing and oven dried at $105{ }^{0} \mathrm{C}$ for 24 hours while the profile samples were air dried at room temperature, crushed and passed through a $2 \mathrm{~mm}$ sieve and analyzed for soil $\mathrm{pH}$ in 1:1 soil to water suspension using a $\mathrm{pH}$ meter (7). Soil organic carbon was by the Walkley and Black method (8). Particle size distribution was by the hydrometer method of Bouyoucos (9) while bulk density was by the core method of (10). Total porosity was determined from the relation, $1-\mathrm{Bd} / \mathrm{Pd}$ X 100 (10) while soil moisture was determined using the gravimetric method (5).

\section{RESULTS}

Sand and silt had the same trend of decreasing with increased soil depths in soils under Alluvium, Coastal Plain Sands and Shale Mixed with Sandstone and Clay. Clay increased with increased soil depths in soils under Alluvium and Coastal Plain Sands parent materials but decreased with increased soil depths in soils under basement complex rocks and shale mixed with sandstone and clay (Table 1). Soil $\mathrm{pH}$ and organic matter content of the soils decreased with increased soil depths in all the locations (Table 1). Bulk density values increased with increased soil depths in all the locations with remarkably high values in the lower depths of soils under alluvium $\left(1.90 \mathrm{gcm}^{-3}\right)$, Coastal Plain Sands $\left(1.71 \mathrm{gcm}^{-3}\right)$ and basement complex $\left(1.86 \mathrm{gcm}^{-3}\right)$. Soils under shale mixed with sandstone and clay had moderately high soil bulk density at the sub soil $\left(1.51 \mathrm{~g} \mathrm{~cm}^{-3}\right)$ (Figure 1). Total porosity decreased with increased soil depths in all the locations with highest values of $55.31 \%$ and $43.10 \%$ at the top and lower depths of soils under shale mixed with sandstone and clay respectively (Figure 2). The lowest top soil value for total porosity was observed in soils under basement complex rocks $(30.42 \%)$ while the lowest sub soil value of total porosity (28.22\%) was recorded in soils under alluvium (Figure 2). Soil moisture contents increased with increased soil depths in all the locations and were generally low in soils under coastal plain sands, basement complex and shale mixed with sandstone and clay. Soils under alluvium had the highest moisture content values of 80.20 and $71.11 \%$ at the top and sub soils respectively (Figure 3).

\section{Influence of parent materials on physical properties of the soils}

Sand, silt, bulk density, moisture content and total porosity of the soils were significantly $(\mathrm{P}<0.05)$ different due to the influence of the different parent materials (Table 2). Soils developed on Coastal Plain Sand Parent materials and Alluvium had the highest sand content while soils under basement complex rocks had the highest silt, clay content and bulk density values (Table 2). Soils under alluvium had the highest moisture content of $75.66 \%$ while soils under shale mixed with sandstone and clay had the highest total porosity of $49.21 \%$ (Table 2 )

\section{Relationships between soil organic matter, $\mathrm{pH}$ and some physical properties of the soils}

Soil organic matter was positively and significantly $(\mathrm{r}=0.928, \mathrm{P}<0.01) ;(\mathrm{r}=0.818) ;(\mathrm{r}=1.000, \mathrm{P}<0.01)$; and $\mathrm{r}$ $=1.000, \mathrm{P}<0.01)$ correlated with sand, silt, total porosity and moisture content respectively but was negatively and significantly $(\mathrm{r}=-0.919, \mathrm{P}<0.05)$ and $\mathrm{r}=-1.000, \mathrm{P}<0.01)$ correlated with clay and bulk density respectively in soils under alluvium (Agbarho) (Table 3). Similarly, soil organic matter was positively and significantly $(\mathrm{r}=0.986, \mathrm{P}<0.01) ;(\mathrm{r}=0.916, \mathrm{P}<0.01)$ and $(\mathrm{r}=1.000, \mathrm{P}<0.01)$ correlated with sand, silt and 
total porosity respectively but was negatively and significantly $(\mathrm{r}=-0.992, \mathrm{P}<0.01) \mathrm{r}=-1.000, \mathrm{P}<0.01$ and $\mathrm{r}=$ $-1.000, \mathrm{P}<0.01$ ) correlated with clay, moisture content and bulk density respectively in soils under Coastal plain sands (NIFOR) (Table 4). Similarly, there were positively significant correlations between soil $\mathrm{pH}$ and total porosity; soil $\mathrm{pH}$ and moisture content and significantly negative correlations between soil $\mathrm{pH}$ and bulk density; soil pH and clay; clay and organic matter; clay and sand; clay and silt in soils under alluvium, coastal plain sand, basement complex rocks and shale mixed with sandstone and clay (Tables 3 - 6). There was a negatively significant correlation between bulk density and moisture content in soils under alluvium (Table 3) but a positively significant correlation between bulk density and moisture in soils under coastal plain sand, basement complex and shale mixed with sandstone and clay (Tables $4-6$ ).

\section{DISCUSSIONS:}

The result of the study seemed to suggest that much of the silt content had weathered into clay. This could be buttressed by the lower amount of silt that progressively decreased with increased soil depths in contrast with clay which progressively increased with increased soil depths irrespective of parent materials. The bulk density values of soils of the locations were high at the sub soils. The high bulk density values recorded at the sub soils of these locations could be attributed to the very low organic matter contents in the sub soils which were below the critical level. The organic matter contents of the sub soils were below $20-30 \mathrm{~g} / \mathrm{kg}$ reported for soils of Southern Nigeria (6). According to (11), organic matter had the tendency of reducing bulk density in soils. Increases in total porosity are often correlated with decreased bulk density (4). This indicated that total porosity and bulk density have an inverse relationship in soils. That inverse relationship was observed in this study such that total porosity tended to decrease with increased soil depths in contrast with bulk density which increased with increased soil depths in all the locations irrespective of parent materials. Total porosity values were higher at the top soils when compared with the sub soil values. This indicated that there were more pore spaces for nutrient and water movement at the top soils when compared to the sub soils irrespective of parent materials. Soil $\mathrm{pH}$ was in the acidic ranges as required by oil palm. With respect to the Oil palm, soil $\mathrm{pH}$ range of between $5.0-5.5$ is considered highly suitable (12). (13) studied the biophysical properties of selected soils of Delta state and puts the suitability class of Oil palm in Abbi and Sapele soils with moderate acidity (Soil pH of 5.82 - 6.21) as S3 (marginally suitable) whereas Agbor, Asaba, Bomadi and Ughelli with slightly acidic soil pH (5.1 - 5.5) were classified as S1 (highly suitable) for the cultivation of Oil Palm. With respect to soils of Oil palm, soil pH has been reported to decrease with increased age of the palms (14). The positively significant correlations between soil pH and sand; soil pH and silt; organic matter and sand; organic matter and silt irrespective of parent materials indicates the influence soil $\mathrm{pH}$ and organic matter exert on the particle size distribution of soils, especially fractions between $0.2-0.02 \mathrm{~mm}$ (sand and silt). The positively significant correlations between moisture and bulk density in soils formed under coastal plain sand, basement complex rocks and shale mixed with sandstone and clay underscores the influence of water on bulk density of soils. This could be buttressed by the negatively significant correlation obtained between bulk density and moisture content of soils under alluvium in Agbarho. As expected, there was a negatively significant correlation between total porosity and bulk density irrespective of the soils parent materials.

\section{CONCLUSIONS}

The following conclusions can be drawn for soils of the oil palm belt of Nigeria-

1. Effects of sand and silt contents on organic matter was found to be higher than clay contents of the soils 2. For soils under alluvium parent materials, the degree of acidity or alkalinity (soil $\mathrm{pH}$ ) was dependent on moisture contents of the soils and was not true for soils under coastal plain sands, basement complex rocks and shale mixed with sandstone and clay. It is recommended that organic materials should be ploughed back constantly to soils under oil palm for improved soil structure, texture, bulk density and moisture contents of soils under oil palm in the belt of its cultivation.

Acknowledgements: The authors are grateful to the Executive Director of the Nigerian Institute for Oil Palm Research (NIFOR) for approval to commence this study and Officers in Charge of NIFOR experimental stations at Onishere in Ondo state, Ubiaja in Edo state and Agbarho in Delta state who assisted in the profile digging and providing other logistics for the successful completion of the field work.

Funding: This research work was funded by the Nigerian Institute for Oil Palm Research (NIFOR) as part of funding for post graduate studies grant.

Conflict of Interest: The authors declare that there is no conflict of interest with respect to this manuscript.

\section{REFERENCES}

(6) Agboola, A.A., Ndaeyo N.U., and Kalu O.I. 1998. Soil fertility management alternatives to Inorganic Fertilizer use. In O. Babalola; G.A. Babajide and S. Mustapha (Eds.), Soil management for sustanaible Agriculture and environmental harmony, Proc. $24^{\text {th }}$ 
Annual Conference of Soil Science Society of Nigeria. (pp. 1-9). Bauchi. $7^{\text {th }}-11^{\text {th }}$ December, 1998.

(1) Bassey, O. I. 2016. Overview of oil palm production in Nigeria, comparative, social and environmental impacts: the case of Ekong Amaku Community in Cross River State, Nigeria. Institute of Social Science, Erasmus University of Rotterdam. $10 \mathrm{pp}$.

(5) Biswas T. D. and Mukherjee S. K. 1994. A Textbook of Soil Science. Tata McGraw Hill Publishing Company Limited. $315 \mathrm{pp}$

(10) Blake, G.R. and Hartge K.H. 1986. Bulk density. In: Methods of Soil Analysis, Part I. Physical and mineralogical Methods. A Klute (ed) Am. Soc. Agron. Madison, 101, USA: 365-375

(4) Brady, W.C. and Weil, R.R. 2002. The nature and properties of soil. Thirteeth Edition, Pearson Education. 976 pp.

(12) Corley, R.H.V. and Tinker P.B. 2003. The Oil palm. 4th Edition. UK Blackwell Science Ltd Oxford.

(9) Gee, G. W. and Or, D. 2002. Particle size distribution. In: Dane J.H and Topp. G.C. (eds). Methods of soil Analysis. Part 4, Physical methods. Soil Sci. Am Book Series No.5, ASA and SSSA, Madison, W.I. PP 255-293.

(7) Hendershort, W. H., Lalande, H., Duquette, M. 1993. Soil rreaction and exchangeable acidity. In: Carter M. R. (ed). Soil sampling and methods of soil analysis. Canadian Soc. Soil Sci. Lewis Publishers, London, PP $141-145$

(8) Nelson D. W. and Sommers L. E. (1996). Total Carbon; Organic carbon and organic matter. In: methods of soil analysis. Part 3. Chemical methods. SSSA Book Series No 5 (Eds: D. L. Sparks, A. L. Page, P. A. Helmke, R. H. Loeppert, P. N. Soltanpour, M. A. Tabatabai) pp $961-1010 \quad$ (SSSA, ASA, Madison, WI)

(14) Ng, P. H.C., Gan H. H. and Goh K. J. 2011. Soil nutrient changes in Ultisols under oil palm in Johor, Malaysia. Journal of Oil Palm \& The Environment. 2: 93-104

(3) Ogunkunle A. O., U. Omoti, A. E. Aghimien and A. E. Isenmila 1999. Characteristics, classification and agricultural potential of some Niger Delta soils in Nigeria. Communications in Soil Science and Plant Analysis 30: 663 - 675

(2) Osayande P. E., P. O. Oviasogie and E. R. Orhue 2019. Soil fertility assessment of the NIFOR Inland Valley for Raphia palms cultivation. Nigerian Journal of Palms \& Oil Seeds 18: $81-90$

(13) Osayande P. E., Orhue E. R. Oviasogie P. O., Oneju A. A. and Edokpayi A. E. 2016. Biophysical properties of selected areas of Delta state and their suitability assessment for Coconut, Raphia and Oil Palms cultivation. Biological and environmental science journal for the tropics 13 (1): 95 - 101.

(11) Umeugochukwu O.P., Ezeaku P.I., Chude V.O. and Nnaji G.U. 2012. Impact of soil erosion on land degradation in Uga, SouthEastern, Nigeria Nigerian Journal of Soil Science: 22 (1):26-36 
Table 1: Physical properties of soils under oil palm in some locations of Southern Nigeria

\begin{tabular}{|c|c|c|c|c|c|c|c|}
\hline Location & $\begin{array}{l}\text { Depth } \\
(\mathrm{cm}) / \\
\text { Parent M. }\end{array}$ & $\begin{array}{l}\text { Soil } \\
\mathrm{pH} 1: 1\left(\mathrm{H}_{2} \mathrm{O}\right)\end{array}$ & $\mathrm{OM}$ & $\begin{array}{l}\text { Sand } \\
\leftarrow\end{array}$ & $\begin{array}{l}\text { Silt } \\
\mathrm{g} / \mathrm{kg}\end{array}$ & $\begin{array}{l}\text { Clay } \\
\rightarrow\end{array}$ & $\begin{array}{l}\text { Textural } \\
\text { Class }\end{array}$ \\
\hline \multirow[t]{6}{*}{ Agbarho: } & Alluvium & & & & & & \\
\hline & $0-15$ & $5.60^{\mathrm{a}}$ & $24.19^{\mathrm{a}}$ & $899.7^{\mathrm{a}}$ & $57.0^{\mathrm{a}}$ & $43.3^{\mathrm{a}}$ & Sand \\
\hline & $15-30$ & $5.37^{\mathrm{a}}$ & $10.08^{\mathrm{b}}$ & $883.5^{\mathrm{b}}$ & $53.7^{\mathrm{a}}$ & $62.8^{b}$ & Sand \\
\hline & $30-45$ & $5.33^{\mathrm{a}}$ & $5.03^{\mathrm{c}}$ & $875.1^{b}$ & $53.7^{\mathrm{a}}$ & $71.1^{b}$ & Loamy sand \\
\hline & $45-90$ & $4.93^{\mathrm{a}}$ & $3.04^{\mathrm{cd}}$ & $860.2^{\mathrm{c}}$ & $52.0^{\mathrm{a}}$ & $87.8^{c}$ & Loamy sand \\
\hline & $90-120$ & $4.73^{\mathrm{a}}$ & $1.23^{\mathrm{d}}$ & $851.9^{c}$ & $47.0^{\mathrm{a}}$ & $101.1^{\mathrm{c}}$ & Loamy sand \\
\hline \multirow[t]{7}{*}{ NIFOR: } & Coastal & & & Plain & Sand & & \\
\hline & $0-15$ & $5.53^{\mathrm{a}}$ & $10.03^{\mathrm{a}}$ & $948.5^{\mathrm{a}}$ & $35.3^{\mathrm{a}}$ & $22.8^{\mathrm{a}}$ & Sand \\
\hline & $15-30$ & $5.33^{\mathrm{ab}}$ & $6.61^{\mathrm{ab}}$ & $895.2^{\mathrm{ab}}$ & 35.3 & $69.5^{\mathrm{ab}}$ & Sand \\
\hline & $30-45$ & $5.20^{\mathrm{ab}}$ & $4.81^{\mathrm{ab}}$ & $858.0^{\mathrm{b}}$ & $32.0^{\mathrm{a}}$ & $106.8^{b c}$ & Loamy sand \\
\hline & $45-60$ & $5.00^{\mathrm{ab}}$ & $2.88^{\mathrm{b}}$ & $851.9^{\mathrm{b}}$ & $28.7^{\mathrm{a}}$ & $116.1^{\mathrm{bc}}$ & Loamy sand \\
\hline & $60-90$ & $4.77^{b}$ & $1.93^{\mathrm{b}}$ & $835.2^{\mathrm{b}}$ & $25.3^{\mathrm{a}}$ & $137.8^{\mathrm{c}}$ & Loamy sand \\
\hline & $90-120$ & $4.77 b$ & $1.93^{\mathrm{b}}$ & & & & \\
\hline \multirow[t]{7}{*}{ Onishere: } & Basement & & & Complex & & & \\
\hline & $0-15$ & $6.77^{\mathrm{a}}$ & $22.80 \mathrm{a}$ & $847.1^{\mathrm{a}}$ & $123.0^{\mathrm{a}}$ & $36.8^{\mathrm{a}}$ & Loamy Sand \\
\hline & $15-30$ & $6.33^{\mathrm{b}}$ & $16.80 \mathrm{a}$ & $815.2^{\mathrm{a}}$ & $103.7^{\mathrm{a}}$ & $81.1^{\mathrm{a}}$ & Loamy Sand \\
\hline & $30-45$ & $6.23^{b}$ & $8.90 \mathrm{~b}$ & $780.2^{\mathrm{a}}$ & $85.3^{\mathrm{a}}$ & $134.2^{\mathrm{b}}$ & Sandy Loam \\
\hline & $45-60$ & $6.23^{\mathrm{b}}$ & $7.70 \mathrm{~b}$ & $775.2^{\mathrm{a}}$ & $83.7^{\mathrm{a}}$ & $141.1^{\mathrm{b}}$ & Sandy Loam \\
\hline & $60-90$ & $6.23^{\mathrm{b}}$ & $5.60 \mathrm{bc}$ & $770.5^{\mathrm{a}}$ & $77.0^{\mathrm{a}}$ & $152.5^{\mathrm{b}}$ & Sandy Loam \\
\hline & $90-120$ & $6.07 \mathrm{c}$ & $4.40 \mathrm{c}$ & $772.9^{a}$ & $77.0^{\mathrm{a}}$ & $152.8^{\mathrm{b}}$ & Sandy Loam \\
\hline \multirow[t]{7}{*}{ Ubiaja: } & Shale & & & Mixed & With & Sandstone & And Clay \\
\hline & $0-15$ & $6.13^{\mathrm{ab}}$ & $17.37 \mathrm{a}$ & $937.4^{\mathrm{ac}}$ & $57.3^{b}$ & $39.0^{\mathrm{a}}$ & Sand \\
\hline & $15-30$ & $5.93^{\mathrm{bc}}$ & $8.17 b$ & $901.9^{b c}$ & $42.0^{\mathrm{ab}}$ & $56.1^{\mathrm{a}}$ & Sand \\
\hline & $30-45$ & $5.47^{\mathrm{c}}$ & $5.39 b$ & $876.5^{\mathrm{b}}$ & $38.7^{\mathrm{ab}}$ & $66.1^{\mathrm{a}}$ & Loamy Sand \\
\hline & $45-60$ & $5.07^{\mathrm{c}}$ & $3.11 b c$ & $846.9^{b}$ & $37.0^{\mathrm{ab}}$ & $114.5^{\mathrm{b}}$ & Loamy Sand \\
\hline & $60-90$ & $4.93^{\mathrm{cd}}$ & $2.04 b c$ & $787.4^{\mathrm{d}}$ & $28.7^{\mathrm{ab}}$ & $177.8^{\mathrm{c}}$ & Sandy Loam \\
\hline & $90-120$ & $4.70^{\mathrm{cd}}$ & $1.24 \mathrm{~cd}$ & $785.2^{\mathrm{d}}$ & $23.7^{\mathrm{a}}$ & $184.0^{\mathrm{c}}$ & Sandy Loam \\
\hline
\end{tabular}

Table 2: Influence of parent materials on the physical properties of the soils

\begin{tabular}{|c|c|c|c|c|c|c|}
\hline Parent material/Location & Sand & Silt & Clay & $\begin{array}{l}\text { Bulk } \\
\text { Density }\end{array}$ & Moisture & Porosity \\
\hline Alluvium(Agbarho) & $870.10 \mathrm{ab}$ & $52.70 \mathrm{a}$ & $73.20 \mathrm{a}$ & $1.62 \mathrm{ab}$ & $75.66 \mathrm{a}$ & $38.51 \mathrm{a}$ \\
\hline Coastal plain Sand (NIFOR) & $870.70 b$ & $30.30 \mathrm{~b}$ & $98.50 \mathrm{a}$ & $1.61 \mathrm{ab}$ & $7.27 \mathrm{~b}$ & $39.38 \mathrm{a}$ \\
\hline Basement Complex Rock(Onishere) & $793.50 \mathrm{c}$ & $91.60 \mathrm{c}$ & $116.40 \mathrm{a}$ & $1.85 b$ & $14.07 \mathrm{~b}$ & $30.08 \mathrm{a}$ \\
\hline Shale mixed with sandstone and clay (Ubiaja) & $855.90 \mathrm{abd}$ & $37.90 \mathrm{~b}$ & $106.20 \mathrm{a}$ & $1.35 \mathrm{a}$ & $12.24 b$ & $49.21 b$ \\
\hline $\mathrm{SE}+$ & 42.85 & 11.47 & NS & 0.23 & 9.51 & 8.46 \\
\hline
\end{tabular}

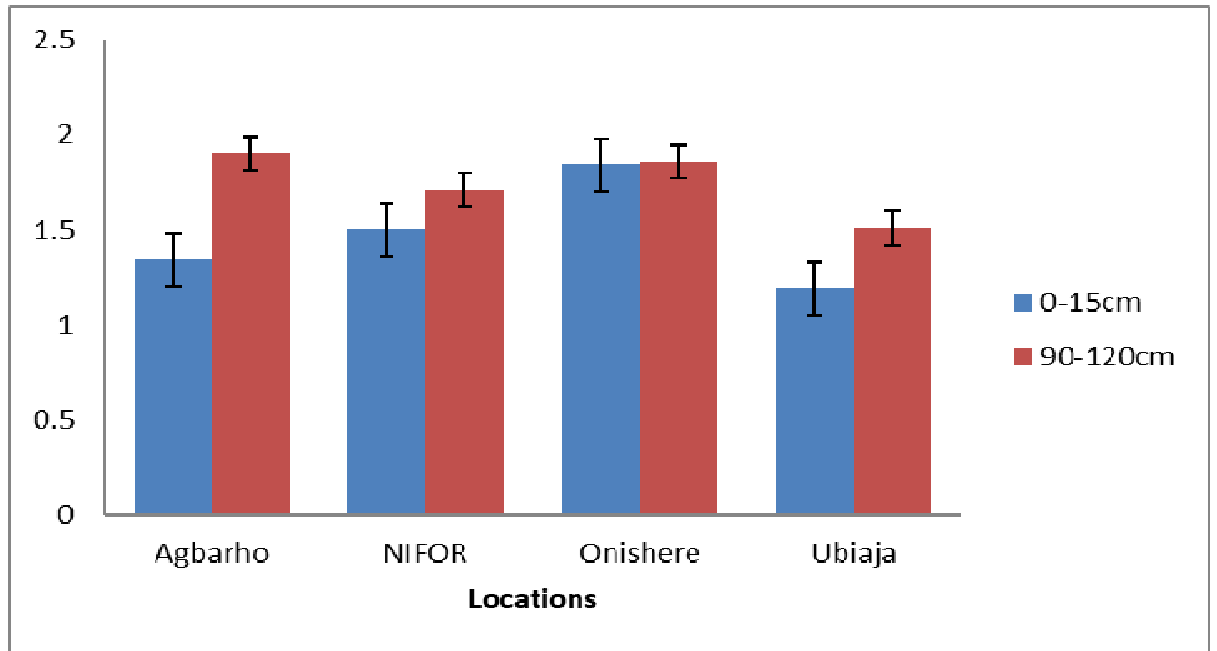

Figure 1: Bulk density $\left(\mathrm{gcm}^{-3}\right)$ of the soils 


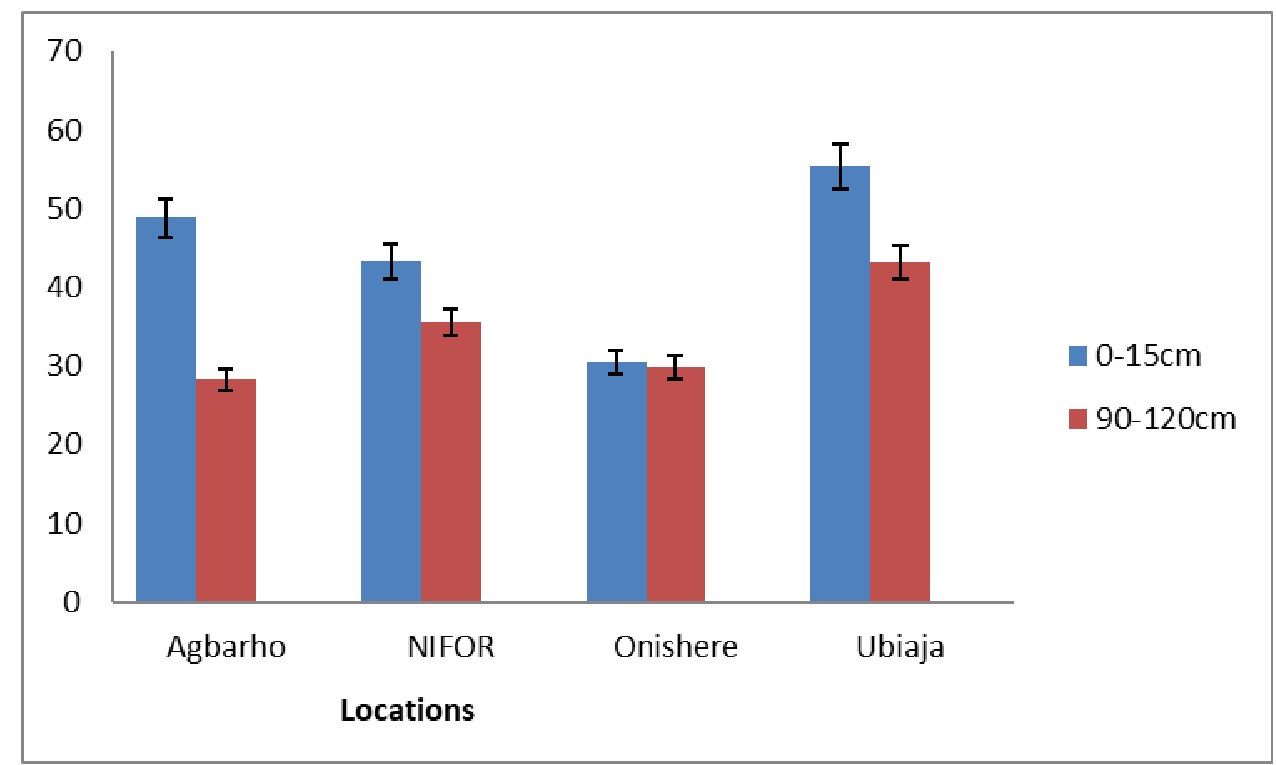

Figure 2: Total porosity of the soils

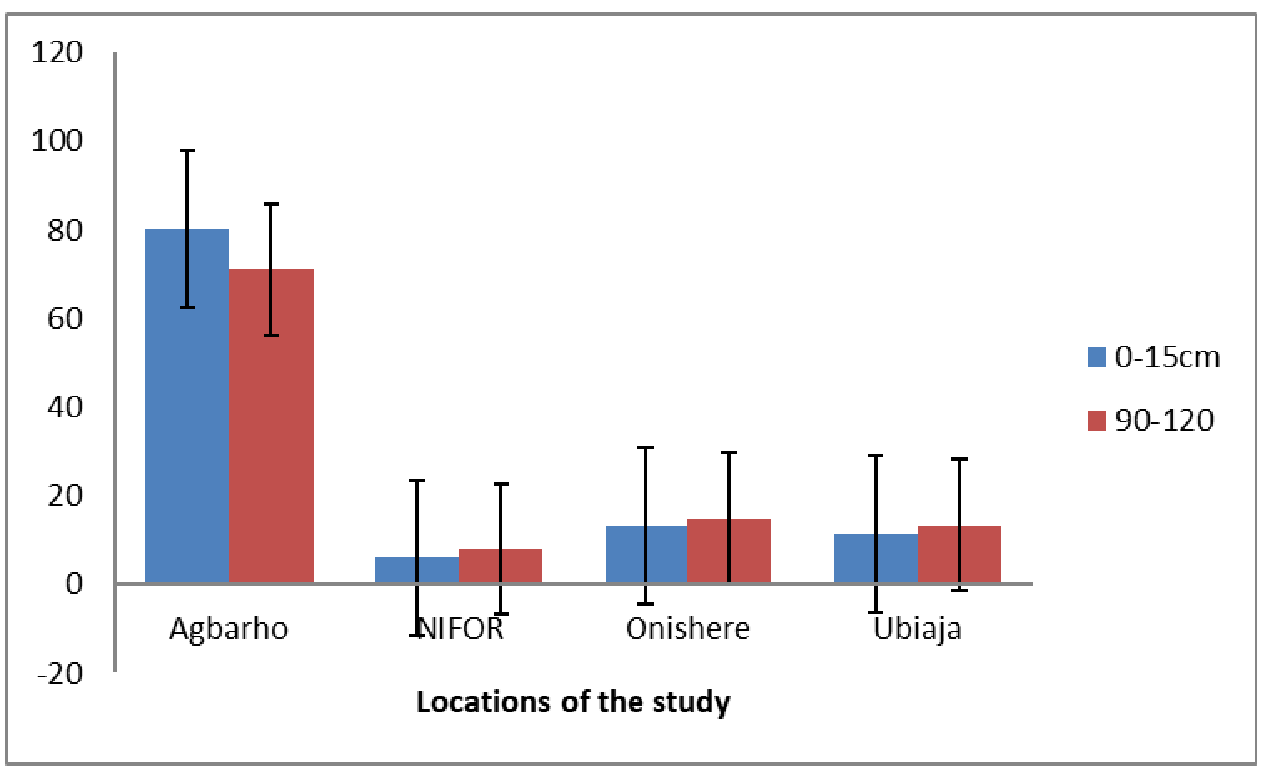

Figure 3: Moisture content (\%) of the soils

Table 3: Relationship between soil organic matter, $\mathrm{pH}$ and physical properties of Agbarho soils

\begin{tabular}{lllllllll}
\hline & $\mathrm{pH}$ & $\mathrm{OM}$ & Sand & Silt & Clay & Porosity & Moisture & BD \\
\hline $\mathrm{pH}$ & 1 & & & & & & & \\
$\mathrm{OM}$ & 0.840 & 1 & & & & & & \\
Sand & $0.979^{* *}$ & $0.928^{*}$ & 1 & & & & & \\
Silt & $0.946^{*}$ & 0.818 & $0.928^{*}$ & 1 & & & & \\
Clay & $-0.983^{* *}$ & $-0.919^{*}$ & $-0.998^{* *}$ & $-0.949^{*}$ & 1 & & & \\
Porosity & $1.000^{* *}$ & $1.000^{* *}$ & $1.000^{* *}$ & $1.000^{* *}$ & $-1.000^{* *}$ & 1 & & \\
Moisture & $1.000^{* *}$ & $1.000^{* *}$ & $1.000^{* *}$ & $1.000^{* *}$ & $-1.000^{* *}$ & $1.000^{* *}$ & 1 & \\
BD & $-1.000^{* *}$ & $-1.000^{* *}$ & $-1.000^{* *}$ & $-1.000^{* *}$ & $1.000^{* *}$ & $-1.000^{* *}$ & $-1.000^{* *}$ & 1 \\
\hline
\end{tabular}

$\mathrm{OM}=$ organic matter, $\mathrm{BD}=$ bulk density

*Correlation is significant at 0.05 level

** Correlation is significant at 0.01 level 
Table 4: Relationship between soil organic matter, $\mathrm{pH}$ and physical properties of NIFOR soils

\begin{tabular}{lllllllll}
\hline & $\mathrm{pH}$ & $\mathrm{OM}$ & Sand & Silt & Clay & Porosity & Moisture & BD \\
\hline $\mathrm{pH}$ & 1 & & & & & & & \\
$\mathrm{OM}$ & $0.968^{* *}$ & 1 & & & & & & \\
Sand & $0.930^{* *}$ & $0.986^{* *}$ & 1 & & & & & \\
Silt & $0.979^{* *}$ & $0.916^{* *}$ & $0.866^{*}$ & 1 & & & & \\
Clay & $-0.956^{* *}$ & $-0.992^{* *}$ & $-0.996^{* *}$ & $-0.904^{*}$ & 1 & & & \\
Porosity & $1.000^{* *}$ & $1.000^{* *}$ & $1.000^{* *}$ & - & $-1.000^{* *}$ & 1 & & \\
Moisture & $-1.000^{* *}$ & $-1.000^{* *}$ & $-1.000^{* *}$ & - & $1.000^{* *}$ & $-1.000^{* *}$ & 1 & \\
BD & $-1.000^{* *}$ & $-1.000^{* *}$ & $-1.000^{* *}$ & - & $1.000^{* *}$ & $-1.000^{* *}$ & $1.000^{* *}$ & 1 \\
\hline
\end{tabular}

$\mathrm{OM}=$ organic matter, $\mathrm{BD}=$ bulk density

*Correlation is significant at 0.05 level

** Correlation is significant at 0.01 level

Table 5: Relationship between soil organic matter, $\mathrm{pH}$ and physical properties of Onishere soils

\begin{tabular}{lllllllll}
\hline & $\mathrm{pH}$ & $\mathrm{OM}$ & Sand & Silt & Clay & Porosity & Moisture & BD \\
\hline $\mathrm{pH}$ & 1 & & & & & & & \\
OM & $0.936^{* *}$ & 1 & & & & & & \\
Sand & $0.923^{* *}$ & $0.982^{* *}$ & 1 & & & & & \\
Silt & $0.936^{* *}$ & $0.986^{* *}$ & $0.994^{* *}$ & 1 & & & & \\
Clay & $-0.923^{* *}$ & $-0.989^{* *}$ & $-0.998^{* *}$ & $-0.998^{* *}$ & 1 & & & \\
Porosity & 0.405 & 0.214 & -0.203 & 0.159 & -0.151 & 1 & & \\
Moisture & -0.456 & -0.276 & 0.163 & -0.209 & 0.199 & $-0.990^{* *}$ & 1 & \\
BD & -0.456 & -0.276 & -0.203 & -0.209 & 0.199 & $-0.990^{* *}$ & $1.000^{* *}$ & 1 \\
\hline
\end{tabular}

*Correlation is significant at 0.05 level

** Correlation is significant at 0.01 level

Table 6: Relationship between soil organic matter, $\mathrm{pH}$ and physical properties of Ubiaja soils

\begin{tabular}{|c|c|c|c|c|c|c|c|c|}
\hline & $\mathrm{pH}$ & $\mathrm{OM}$ & Sand & Silt & Clay & Porosity & Moisture & $\mathrm{BD}$ \\
\hline $\mathrm{pH}$ & 1 & & & & & & & \\
\hline $\mathrm{OM}$ & $0.907 *$ & 1 & & & & & & \\
\hline Sand & $0.966 * *$ & $0.890^{*}$ & 1 & & & & & \\
\hline Silt & $0.928 * *$ & $0.957 * *$ & $0.954 * *$ & 1 & & & & \\
\hline Clay & $-0.939 * *$ & -0.805 & $-0.983 * *$ & $-0.900^{*}$ & 1 & & & \\
\hline Porosity & 0.265 & 0.373 & 0.200 & 0.344 & -0.208 & 1 & & \\
\hline Moisture & -0.265 & -0.373 & -0.200 & -0.344 & 0.208 & $-0.1000 * *$ & 1 & \\
\hline $\mathrm{BD}$ & -0.265 & -0.373 & -0.200 & -0.344 & 0.208 & $-0.100 * *$ & $1.000 * *$ & 1 \\
\hline
\end{tabular}

*Correlation is significant at 0.05 level

** Correlation is significant at 0.01 level 